\title{
The Effect of Transcutaneous Auricular Stimulation on Anxiety before Colposcopy: A Randomized Clinical Trial
}

\author{
Samaneh Jouya, Nahid Golmakani \\ Nursing and Midwifery Care Research Center, Mashhad University of Medical Sciences, Mashhad, Iran
}

\author{
SUMMARY
}

Women experience a high level of anxiety and negative emotional responses during colposcopy, which results in women's' unwillingness to return for follow-up. Transcutaneous auricular stimulation may be useful in reducing anxiety. Therefore, the aim of this study was to determine the effect of transcutaneous auricular stimulation on anxiety before colposcopy.

This randomized controlled clinical trial study was performed on 65 female candidates for colposcopy who were referred to Ghaem Hospital, Mashhad, Iran, in 2017. Women were randomized into one of the two groups. In the intervention group, a pointer Excel device was used for forty minutes before colposcopy; electrical stimulation at 4 points (Shenmen, relaxation, tranquillizer and endocrine) was performed on ears, with the frequency of $2 \mathrm{~Hz}$ for 30 seconds at each point. Women received routine care in the control group. The anxiety level was assessed by Spielberger Questionnaire before intervention and also 40 minutes after intervention. Data analysis was performed using the $t$-test, paired t-test, and MannWhitney test in SPSS software, version16. $P$ value less than 0.05 was considered significant. After intervention, the state anxiety score was $43.9 \pm 9.19$ in the control group and $54.3 \pm 9.07$ in the intervention group, and the difference between the two groups was statistically significant $(P=0.00)$, while there was no significant difference in the level of trait anxiety in the two groups $(P=0.21)$. Regarding the reduction of state anxiety level after intervention, transcutaneous auricular stimulation is recommended as a suitable method to reduce anxiety of patients who are candidates for colposcopy.

Key words: anxiety, colposcopy, auriculotherapy, electrical stimulation

Corresponding author:

Nahid Golmakani

email: Golmakanin@mums.ac.ir 


\section{INTRODUCTION}

Cervical cancer is the second most common cancer among women aged 65 years and over (1). It is also the fifth cause of death in female cancer deaths, and the second cause of death in women aged $15-44$ years (2). By the Pap smear screening program, this disease can be diagnosed early, with reduction of death rate (3). More recently, it has been estimated that up to 5,000 deaths per year are likely to be prevented by screening (1). The standard of care for patients with abnormal cervical smear result is to perform colposcopy and directed biopsy (4). Colposcopy is performed to aid identify the transformation zone from which cervical neoplasia originates (1).

Colposcopy is the visualization of the cervix by stereoscopic binocular microscope with high magnification and it facilitates the guided diagnostics or therapeutic biopsy $(5,1)$. Colposcopy-guided biopsies may detect precursor lesions which can lead to the development of cervical cancer; therefore, invasive diagnostic methods such as cone biopsy (conization) is not required (6).

Many women think that the purpose of screening is to detect cancer rather than to prevent it, which results in high levels of anxiety (7). In general, women referred to colposcopy experience high levels of anxiety and stress, like anxiety before a major surgery (8) and anxiety before undergoing embryonic screening tests, with possible abnormal outcomes (4). In a clinical trial study, Jones showed that during colposcopy visits, the mean anxiety score in women was 0.63 and it increased in women who thought they had cancer (70.2\%) (9).

Anxiety is an emotional state that is associated with fear and sudden increases in the activity of the autonomic nervous system (10). Research shows that anxiety increases pain during treatment and care (11). A possibility of malignant diseases and fear of diagnostic procedures causes anxiety in females, which leads to late referral, delay in diagnosing and suffering of patients (12). Also, this disorder can have serious health consequences such as avoiding necessary medical care (13).

To reduce anxiety before colposcopy, in addition to drug treatments, providing non-pharmacological interventions can alleviate anxiety (14). Today, drug therapy is not the best way to alleviate anxiety in patients. Although medications reduce anxiety, they have numerous side effects (11). To reduce anxiety before colposcopy, various non-pharmacological strategies have been used such as educational pamphlets, video and patient education and cognitivebehavioral consultations. However, despite increasing knowledge of people, these strategies cannot reduce anxiety in patients (9). Therefore, there are several methods in complementary therapies that nurses use to help patients to control their anxiety (15), such as massage therapy, exercises, music therapy, yoga and Tai Chi, hypnosis, prayer, religious practices and acupuncture. Some of these methods have some limitations, for example, all patients cannot participate in sports exercises or yoga sessions (16). It seems that auriculotherapy is a method that has less limitation with no negative consequences $(17,18)$. According to auriculotherapy theory, all body organs are reflected on the outer part of the ear and there are certain points on the auricle that can stimulate these organs and their reflection areas to correct the balance and disorder of the parts of the body that has been ill (19). This method creates balance in the body and increases the sense of health in humans (20). In 1990, World Health Organization Director-General (WHO) stated that auriculotherapy is probably the most advanced and best-documented scientific body of all microsystems that are widely used (19). There are various techniques in auriculotherapy, including stimulation of the ear points by needle or seeded labels, hand pressure, heat, laser and electrical stimulation through the skin (21). Auriculotherapy can be used to stimulate energy channels with nerve connections by using The Pointer Plus device that emits an appropriate electrical stimulation flow and sends a message to the brain that helps balance or coordinate the body and mind. In fact, this method is a form of TENS or neural stimulation, which is the best method for generating natural frequencies in the under-treatment nerves (22). Actually, the electrical stimulation of the ear increases the parasympathetic tone and creates temporary sleep, therefore, it creates relaxation, calms the emotions and improves the mood in the patients (23). The stimulation of the reflex points on the ears leads to the release of endogenous opioids from lymphocytes, monocytes, macrophages, and granulocytes in the blood stream, which suppresses the peripheral neuronal terminals. Also, the release of serotonin, nerve growth factor and bradykinin may be responsible for the sedation effect (24). In fact, using TENS on acupressure points may activate nerve signals like acupuncture, leading to hypothalamus stimulation and release of endorphins in the body (25). 
The evidence available on the application of these approaches is very variable. A large number of randomized clinical trials have been conducted to evaluate the efficacy of this medicine. However, there is still controversy over the lack of well-known biophysical mechanisms to justify its effectiveness (26). Some studies confirm the efficacy of electrical stimulation; thus, Di benedetto et al. in their study aimed at comparing the effect of S-adenosine Lmethionine (SAMe) and TENS on early fibromyalgia. The use of TENS treatment per 6 weeks did not reduce pain and depression of the patients, but significantly reduced the patient's anxiety (27). Also, in the study of Liuzhen et al., transcutaneous electrical nerve stimulation (TENS) produced by Han's acupoint nerve stimulator (HANS) for two weeks reduced methadone (MTD) dose, relieved anxiety and depression of heroin addicts during and after detoxification (28).

On the other hand, Karen et al. compared the effectiveness of transcutaneous electrical nerve stimulation (TENS), transcutaneous spinal electroanalgesia (TSE), and placebo (sham TSE) in women with chronic pain following breast cancer treatment to reduce pain and anxiety. Electrical stimulation was performed in duration of three weeks. There was no significant difference between the TENS and TSE groups compared to placebo in reducing pain and anxiety; it is considered that electrical stimulation through the skin is not useful and this issue is still under discussion (29).

In general, there is limited evidence in favor of the efficacy of auriculotherapy on situational anxiety or preoperative anxiety (30). Many of the complementary medicines claimed to be effective are still incompatible with the biomedical model and require more research (31). As these interventions are effective, inexpensive, low-risk and non-invasive, and do not require expensive equipment, nurses can easily carry them out when compared to other kinds of nursing care (21). Cervical cancer is the most common cause of death among the genomic cancers around the world and approximately 275,000 people die each year due to this disease (32). According to the World Health Organization, the uterine cancer in developing countries will be doubled by 2020 (3). Therefore, for the examination of abnormal smears, colposcopy should be done. For that reason, anxiety in women waiting for colposcopy is high, which may have longterm psychosexual problems (8). If there are more differences in the results of electrical stimulation on anxiety, there will be more emphasis on further studies in this field. As there is limited study about transcutaneous auricular stimulation in Iran and there is no study on auriculotherapy effect with electrical stimulation on anxiety before colposcopy, the current study was designed to test the efficacy of transcutaneous auricular stimulation on anxiety before colposcopy.

\section{PARTICIPANTS AND METHODS}

\section{Participants and Procedures}

This controlled randomized clinical trial study with a parallel plan was conducted in the period from May 2017 to April 2018. After the approval of the research by the Ethics Committee of the University and obtaining a referral from the Nursing Midwifery Faculty of Mashhad, Iran, sampling was started. The sample size included 65 persons and the research population consisted of women having abnormal smear results, requiring colposcopy examination. They were referred to Ghaem Hospital, Mashhad. The study population was selected through a convenience sampling method. Based on random numbers in SPSS software, the participants were assigned randomly into the TAS and control group.

The inclusion criteria were: 1) age between 18 to 80 years, 2) having the first experience of colposcopy, 3) non-pregnancy and lactation, 4) lack of addiction to drugs and alcohol, 5) no previous record of psychological disorders and severe diseases, 6) no prior auricular treatment experience in the past six months, 7) normality of vital signs, 8) no stressful news received in the last three months (death in the family, diagnosis of incurable diseases, self-disability or similar cases in the family), and 9) absence of lesion on the ears. On the other hand, the exclusion criteria included: 1) unwillingness to continue participating in intervention, 2) unusual sensitivity to ear touching, 3) presence of inflammation, infection, or itching.

The minimum sample size was calculated to compare the means of two populations. A pilot study was performed on 20 women (10 cases from each group) in order to evaluate the mean and standard deviation of anxiety (48.9 \pm 8.4 in the control group and $40.1 \pm 9.4$ in the TAS group). Finally, the sample size was calculated to be 13 cases for each group at $95 \%$ confidence interval and $80 \%$ power, 
which was increased to 35 cases to avoid the baseline imbalance. Then, written informed consents were obtained and participants were assured by the researcher that they were free to participate or to decline to participate or to withdraw from the research at any time.

A total of 5 subjects were excluded from the study. Three participants in the control group (2 were excluded because they did not complete the questionnaire and one another did not appear on the colposcopy examination) and two participants in the electrical stimulation group were excluded because they did not come on colposcopy day. Eventually, 32 and 33 people remained in the intervention and control group, respectively.

\section{Measures}

Prior to the treatment, the participants completed the demographic information questionnaire (SDC) and colposcopy questionnaire. Patients' anxiety was measured before and 40 minute after the intervention (immediately before colposcopy), by using Spilberger's Anxiety Inventory (STAI) questionnaire. The State-Trait Anxiety Inventory (STAI) for adults was used in this study to assess women's anxiety. This consists of 40 self-reported items that measure state and trait anxiety score range from 20 to 80, with the upper scores indicating upper anxiety levels. This is a validated reliable and sensitive measure of anxiety that has been widely used to assess anxiety in adult populations. The STAI state scale consists of 20 statements that ask people to describe how they feel at a particular moment in time (e.g., calm, tense) rated on a 4-point intensity scale ranging from "not at all" to "very much so". The STAI trait scale consists of 20 statements describing how people generally feel (e.g., confident) rated on a 4-point frequency scale ranging from "almost never" to "almost always" (33).

Validity and reliability of STAI have been confirmed in many studies. Its validity was first approved by Mahram et al. for use in Iran (34). Content validity was used to confirm the validity of this instrument, the SDC and colposcopy information questionnaire, so that after a thorough study of the novel books and articles in the field of research, it was prepared and the content validity of this questionnaire was approved by seven faculty members of the School of Nursing and Midwifery, Mashhad University of Medical Sciences, Mashhad, Iran. After applying their corrective and suggestive comments, they were used as the final tool for collecting information. The reliability of colposcopy questionnaire was confirmed using a test-retest which were performed with an interval of one hour $(r=0.90)$.

Reliability of STAI questionnaire was confirmed by internal consistency method with Cronbach's Alpha on 10 subjects in research units $(r=$ 0.86). Also, the reliability of the Excel pointer was checked in terms of the intensity of the current and frequency, using the Electronic Volt Amp Ohm Meter Digital Multi meter.

\section{Intervention}

Before this project, the researcher acquired the necessary training through the study of reliable sources; participation in the workshop, as well as practical skills required by a specialist consultant (acupuncturist and Chinese medicine specialist) in the field of auriculotherapy confirmed their competence to perform auriculotherapy. During the study, the interventions were conducted by the researcher and were supervised by a specialist consultant. In the intervention group, after the above acupoints were sterilized with $70 \%$ alcohol, transcutaneous auricular stimulation (TAS) was delivered to the outer ears at four acupoints (Figure 1), (Relaxation, Shenmen, Endocrine, and Tranquilizer) using the Pointer Excel II and $2 \mathrm{~Hz}$ frequency and $2 \mathrm{~mA}$ Intensity, for 30 seconds on each acupoint. This intervention was conducted on both ears $40 \mathrm{~min}$ before colposcopy.

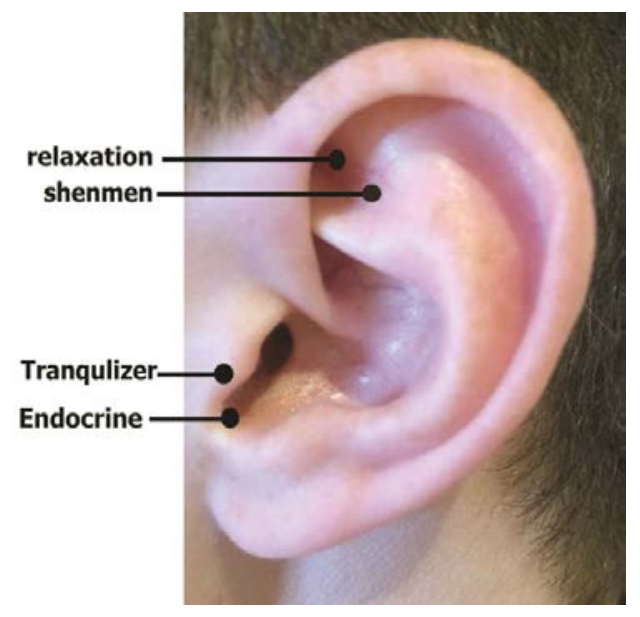

Figure 1. Anatomic points on the ear

Due to ethical considerations, the researcher's contact number was available to the research units and it was pointed out that participants could be ex- 
cluded from the study if they did not wish to continue their cooperation. One day before colposcopy, the researcher called the patients to remind them of the time when they should go to the hospital, and advised them not to use sedation medication 4 hours before going to the hospital. During the course of colposcopy in the control group, in order to remove the anxiety and stress, as with the subjects of the intervention group, the researcher was present along with the research units. None of colposcopy specialists knew about the allocation of subjects in the groups. Also, after auriculotherapy, research units were requested to contact the researcher about any problems and complications such as sensitivity, infection, itching, and the necessary measures to be taken.

Data analysis was done by SPSS software (version 16) and the main variables were analyzed by independent t-test, Mann-Whitney, T-paired, Chisquare, Exact Chi-square, Exact fisher test. To describe personal-social characteristics of research units, descriptive statistics (number, mean and standard deviation) was used; to evaluate the two groups in terms of homogeneity of quantitative variables, independent t-test was used; and finally, to evaluate qualitative variables, Chi-square and
Exact fisher were used. Independent $t$-test and paired t-test were used to compare mean anxiety after the intervention. $\mathrm{P}$ value less than 0.05 was considered significant.

\section{Data analys}

All data collected through the questionnaires were statistically analyzed regarding the study aims. These data were analyzed using SPSS version 16 .

\section{RESULTS}

In this study, 65 women with an average age of $39.2 \pm 10.09$ years were examined. The mean age of getting married was $19.2 \pm 4.8$ years. There was no significant difference among the two groups regarding the demographic and clinical data $(\mathrm{p}>0.05)$ (Table 1). Independent $t$-test showed that there was no significant difference in state anxiety between the two groups before and after the intervention $(\mathrm{P}=$ 0.93 ) and they were homogenous. However, comparing the mean of anxiety at the end of the study in the intervention and control groups, independent t-test showed that the two groups after the intervention showed a significant difference in terms of

Table 1. Demographic and clinical variables by the groups using exact Chi-square test

\begin{tabular}{|c|c|c|c|c|}
\hline \multirow{2}{*}{ Variable } & & \multicolumn{2}{|c|}{ Groups } & \multirow{2}{*}{ Result } \\
\hline & & $\begin{array}{c}\text { TAS } \\
32 \\
\end{array}$ & $\begin{array}{c}\text { control } \\
33\end{array}$ & \\
\hline \multirow{3}{*}{ Education } & Initial & $19(59.4)$ & $15(45.5)$ & \multirow{3}{*}{$p=0.114^{*}$} \\
\hline & Secondary school & $9(28.1)$ & $8(24.2)$ & \\
\hline & Higher education & $4(12.5)$ & $10(30.3)$ & \\
\hline \multirow{3}{*}{ Address } & City & $19(59.4)$ & $24(72.7)$ & \multirow{3}{*}{$\mathrm{p}=0.497^{* *}$} \\
\hline & Village & $11(34.4)$ & $8(24.2)$ & \\
\hline & Suburbs & $2(6.2)$ & $1(3.0)$ & \\
\hline \multirow[t]{2}{*}{ Job } & Housewife & $27(84.4)$ & $29(87.9)$ & \multirow[t]{2}{*}{$p=0.733^{* * *}$} \\
\hline & Employed & $5(15.6)$ & $4(12.1)$ & \\
\hline \multirow{2}{*}{$\begin{array}{c}\text { History of multiple } \\
\text { marriages }\end{array}$} & yes & $4(12.5)$ & $6(20)$ & \multirow[t]{2}{*}{$\mathrm{p}=0.487^{* * *}$} \\
\hline & no & $28(87.5)$ & $24(80)$ & \\
\hline \multirow{4}{*}{ Dyspareunia } & no & $13(41.9)$ & $16(48.5)$ & \multirow{4}{*}{$\mathrm{p}=0.408^{* * *}$} \\
\hline & mild & $14(45.2)$ & $8(24.2)$ & \\
\hline & moderate & $3(9.7)$ & $8(24.2)$ & \\
\hline & severe & $1(3.2)$ & $1(3.2)$ & \\
\hline
\end{tabular}

* Chi-square, ${ }^{* *}$ Exact Chi-square, ${ }^{* * *}$ Exact fisher test

TAS: transcutaneous auricular stimulation 
Table 2. Comparison of mean and standard deviation of the state anxiety of female candidates for colposcopy before and after intervention given by groups

\begin{tabular}{c|c|c|c}
\hline \hline \multirow{2}{*}{$\begin{array}{c}|c| \\
\text { Variable }\end{array}$} & \multicolumn{2}{|c}{ Groups } & \\
\hline State anxiety & 32 & Control & \multirow{2}{*}{ Result of Independent } \\
& $\begin{array}{c}\text { Standard } \\
\text { Test }\end{array}$ & $\begin{array}{c}\text { Standard } \\
\text { deviation } \pm \text { mean }\end{array}$ & \\
\cline { 2 - 4 } & $52.7 \pm 10.3$ & $52.9 \pm 7.8$ & $\mathrm{p}=0.93$ \\
\hline Before intervention & $43.9 \pm 9.1$ & $54.3 \pm 9.0$ & $\mathrm{p}=0.00$ \\
\hline After intervention & $\mathrm{p}=0.00$ & $\mathrm{p}=0.12$ & \\
\hline Result of paired sample t-test & &
\end{tabular}

TAS: transcutaneous auricular stimulation

Table 3. Comparison of the mean and standard deviation of the trait anxiety of female candidates for colposcopy before and after the intervention given by groups

\begin{tabular}{c|c|c|c}
\hline \multirow{2}{*}{} & \multicolumn{2}{|c}{ Groups } & \\
\hline \multirow{2}{*}{$\begin{array}{c}\text { Variable } \\
\text { State anxiety }\end{array}$} & $\begin{array}{c}\text { TAS } \\
\text { St }\end{array}$ & $\begin{array}{c}\text { Control } \\
33\end{array}$ & \multirow{2}{*}{$\begin{array}{c}\text { Result of Independent } \\
\text { T test }\end{array}$} \\
\cline { 2 - 4 } & $\begin{array}{c}\text { Standard } \\
\text { Deviation } \pm \text { mean }\end{array}$ & $\begin{array}{c}\text { Standard } \\
\text { deviation } \pm \text { mean }\end{array}$ & \\
\hline Before intervention & $47.8 \pm 9.2$ & $47.4 \pm 8.1$ & $\mathrm{p}=0.86$ \\
\hline After intervention & $45.3 \pm 8.4$ & $47.9 \pm 7.9$ & $\mathrm{p}=0.21$ \\
\hline Result of paired t-test & $\mathrm{p}=0.00$ & $\mathrm{p}=0.08$ & \\
\hline \hline
\end{tabular}

TAS: transcutaneous auricular stimulation

the mean of state anxiety scores $(P=0.00)$. The results of intra-group study showed that there was a significant difference in the level of state anxiety after intervention compared to the before intervention $(\mathrm{P}=0.00)$; however, in the control group, state anxiety after intervention was significantly higher than before; however, a significant difference was not found ( $\mathrm{P}=0.12)$ (Table2).

Independent t-test showed that there was no significant difference between the two groups before and after intervention $(p=0.86)$ and they were homogenous. Also, in terms of mean scores of trait anxiety by comparing the mean of anxiety in the intervention and control groups at the end of the study, independent $t$-test showed that there was no significant difference between the two groups after the intervention $(p=0.21)$.

The result of in-group study showed a significant difference in trait anxiety before and after intervention $(P=0.00)$, but in the control group there was no significant difference in trait anxiety before and after the intervention ( $\mathrm{P}=0.08)$ (Table 3$)$.

\section{DISCUSSION}

In the present study, by comparing state anxiety in the two groups after intervention, the mean of state anxiety in the TAS group was $43.9 \pm$ 9.1, which was significantly different from the control group $(54.3 \pm 9.0)$. Also, in the TAS group, the mean of state anxiety after intervention decreased significantly when compared to the score before the study, while in the control group state anxiety increased when compared to the values before study; this difference was not significant, which could be due to an increase in the anxiety immediately before the invasive procedure. As shown in the study by Karst et al., after acupuncture of the ear about 30 minutes before dental surgery, in the control group anxiety was evident from 53.03 to 56.5 immediately 
before surgery (35). Also, in Hashemi's study, before cardiac catheterization, $66 \%$ of patients in the control group had severe anxiety, whose anxiety levels reached $84 \%$ one hour after the intervention and immediately before the procedure (36). Therefore, despite an increase in the state anxiety level of patients immediately before invasive procedures, the electrical stimulation of the ear could reduce patient anxiety immediately before colposcopy.

However, comparing the condition before the study (with internal evaluation) in the control group, there was no significant difference in the amount of trait anxiety after the study, while in the TAS group, the level of trait anxiety after intervention decreased significantly compared to the values before study, which may be due to placebo effects of this method. Therefore, there was no significant difference between the mean of trait anxiety in the TAS group after the intervention compared to the control group, as trait anxiety is a chronic and persistent response and a constant personality trait (37) and these patients have constant concern about their physical health (38). Furthermore, auriculotherapy was performed several weeks for chronic illness (19), while in this study TAS was applied for one session, so it may be necessary to perform auriculotherapy for weeks before colposcopy (39) to influence this type of anxiety and worry.

In studies that used the transcutaneous electrical stimulation technique for intervention, several studies have been consistent with the current study, including De Benedetto et al.'s randomized clinical trial the aim of which was "to compare the effects of SAMe and electrical stimulation of the skin (TENS) for primary fibromyalgia". Patients were classified either in SAMe or in TENS groups for six weeks of treatment. TENS patients performed five morning sessions in the week. The results showed that based on Hamilton's anxiety rating scale, TENS could significantly reduce the anxiety level of patients, despite the fact that it did not exert effect on pain and depression in patients (27). In Hamilton's study, the study population was different from the present study and also the number of sessions and duration of electrical stimulation of the skin was greater than in the present study. In this study, an electrical stimulation, based on Spilberger scale, was able to effectively decrease the anxiety of patients.

In a study by Liuzhen et al, a clinical trial was conducted to determine the effect of $10-2 \mathrm{~Hz}$ electric stimulation of the skin on the reduction of metha- done dosage and improving heroin withdrawal symptom in adults such as depression and anxiety. The results of this study are also consistent with the present study. The results showed that electrical stimulation of the skin by Hans acupoint nerve stimulator (HANS) significantly reduced the amount of methadone consuming, anxiety and depression for two weeks for patients during and after heroin withdrawal (28). In that study, an electrical stimulation device was installed on the body of the patient, but in our study electrical stimulation was performed on ears; on the other hand, as in our study, electrical stimulation entailed only one session and could reduce the patients' anxiety. In their study, the electrical stimulation apparatus and its type of function differed from those used in our study.

In keeping with our study, Karen et al. performed two different methods of electrical stimulation in three groups: transcutaneous electrical nerve stimulation (TENS), transcutaneous spinal electro-analgesia (TSE), and a placebo (sham TSE) for three weeks. The results demonstrated no significant difference in pain and anxiety among the women with chronic pain after breast cancer treatment following the application of electrical stimulation. It is believed that electrical stimulation through the skin is not useful and this issue is still under discussion (29). This discrepancy can be ascribed to the difference in the implementation of the intervention. In this study, the patients themselves did the intervention at home and they were not likely to have the appropriate selective points stimulated, whereas in the present study, electrical stimulation was conducted by the trained researcher. Total differences can be due to the difference in target groups, research environments, used points, duration of electrical stimulation, and time to assess anxiety. Given that patients in the intervention group had less state anxiety in comparison to the control group, it can be concluded that in the present study the electrical stimulation of the ear with an Excel pointer was an easy, new and available method, that it had a significant effect on reducing the state anxiety of female candidates for colposcopy, while it did not affect the trait anxiety.

\section{Limitation}

One of the limitations of the present study was the impossibility of using a placebo group (stimu- 
lation of non-related anxiety points with an only lighton device, without electrical current). Also, the strength of the study is that it is one of the first studies in Iran that has been conducted on the anxiety of female candidates for colposcopy.

\section{CONCLUSION}

Based on the results of this study, auriculotherapy with TAS can be a comfortable and uncomplicated method which can reduce the state anxiety of female candidates for colposcopy. It is an inexpensive and easy-to-access technique used to reduce anxiety before colposcopy. Therefore, it is recommended to midwives and nurses to do this technique during their care, and also it is suggested to conduct further studies on the effect of auriculotherapy on anxiety reduction by selecting different points on the ears.

\section{Acknowledgments}

This study is based on the dissertation of the Midwifery Faculty, Nursing Midwifery Faculty of Mashhad (approved by the Vice-Chancellor of Research of Mashhad University of Medical Sciences) sponsored by the university and registered at the clinical trial database IRCT2017043033717N1. In this way, the researchers are grateful to their supporters and all the participants in this study, the officials of Ghaem hospital (Mashhad), head of the staff and staff of the women's clinic of the Centre.

\section{Conflict of interest}

The authors declared no potential conflicts of interest with respect to the study.

\section{References}

1. Galaal K, Deane K, Sangal S, Lopes AD. Interventions for reducing anxiety in women undergoing colposcopy. Cochrane Database Syst $\operatorname{Rev} 2007 ; 3$

https://doi.org/10.1002/14651858.CD006013.pub2

2. Stark H, Živković A. HPV vaccination: Prevention of cervical cancer in Serbia and in Europe. Acta Fac Med Naiss 2018;35:5-16. https://doi.org/10.2478/afmnai-2018-0001

3. Zandvakili F SZ, Soofizade, N. Diagnostic value of colposcopy and histopathology in patients with abnormal Pap smear and suspicious clinical findings referring to Sanandaj Besat Hospital in 2012-2014. IJOGI 2017;20:1-6. (in persian). https://doi.org/ 10.22038/ijogi.2017.9074
4. Mitchell MF, Schottenfeld D, Tortolero-Luna G, et al. Colposcopy for the diagnosis of squamous intraepithelial lesions: A meta-analysis 1. Obstet Gynecol 1998;91:626-31. https://doi.org/10.1097/00006250-199804000-00029

5. Jouya S, Golmakani N, Mazloum SR, et al. Comparison of the Impacts of Auriculotherapy with Electrical Stimulation and Vaccaria Seeds on Colposcopy Pain: A Randomized Clinical Trial. EBCJ 2018;7:55-62. https://doi.org/10.22038/EBCI.2017.27683.1653

6. Berek JS.Berek and Novak gynecology. In: Ansari S, editor. 15 ed: Golban nashr-Tehran; 2012. (in persian).

7. Walsh JC, Curtis R, Mylotte M. Anxiety levels in 
women attending a colposcopy clinic: a randomised trial of an educational intervention using video colposcopy. Patient Educ Couns 2004;55:247-51.

https://doi.org/10.1016/j.pec.2003.09.012

8. Howells R, Dunn P, Isasi $T$, et al. Is the provision of information leaflets before colposcopy beneficial? A prospective randomised study. BJOG: An Int J Gynaecol Obstet 1999;106:528-34. https://doi.org/10.1111/j.1471-0528.1999.tb08319.x

9. Jones M, Singer A, Jenkins D. The mildly abnormal cervical smear: patient anxiety and choice of management. J R So Med 1996;89:257-60. https://doi.org/10.1177/014107689608900506

10. Mirhosseini H, Nazari Ma, Hashmi T, Yassini sM. The Effect of Transcranial Direct Current Stimulation on Anxiety during treatment of Opiate Addiction via Ultra Rapid Opioid Detoxification under Anesthesia. J Anesth Pain 2015;6:74-82.(in persian).

11. Harorani M ZS, Varvanifarahani P, Norozi M. Investigation on the effectiveness inhalation aromatherapy with Lavender essential oil on the anxiety of patients with burns. Complementary Med J 2016;6:1591-83. (in persian).

12. Orujlu S, Hemmati-Maslakpak M. Effect of nursing interventions on anxiety and vital signs in patients undergoing endoscopy: a randomized clinical trial study. J C N M. 2014;3:36-43(in persian).

https://doi.org/10.17795/nmsjournal25661

13. Milovanović B, Tomović D, Janković SM, et al. Factors influencing the fear of needles among students of medicine and pharmacy. Acta Fac Med Naiss 2017;34:147-58.

https://doi.org/10.1515/afmnai-2017-0016

14. Chan Y, Lee PW, Ng T, et al. The use of music to reduce anxiety for patients undergoing colposcopy: a randomized trial. Gynecol Oncol 2003;91:213-7. https://doi.org/10.1016/S0090-8258(03)00412-8

15. Pourmovahed Z, Zare Zardini H, Vahidi A, Jafari Tadi E. The Effect of Inhalation Aromatherapy on Anxiety Level of the Patients Before Coronary
Artery Bypass Graft Surgery (CABG). J Rafsanjan University Med Sci 2016;15:551-62.(in persian).

16. Tayebi A, Kasra Dehkordi A, Ebadi A, et al. The effect of aromatherapy with lavender essential oil on depression, anxiety and stress in hemodialysis patients: A clinical trial. Evidence Based Care 2015;5:65-74. (in persian).

17. Rajai N, Choopani N, Pishgouyi SAH, Sharififar S. The effect of acupressure on anxiety of patients candidate for coronary angiography. Military Caring Sciences 2015;2:6-13. (in persian). https://doi.org/10.18869/acadpub.mcs.2.1.6

18. Wang S-M, Peloquin C, Kain ZN. The use of auricular acupuncture to reduce preoperative anxiety. Anesthesia \& Analgesia 2001;93:1178-80. https://doi.org/10.1097/00000539-200111000-00024

19. Oleson T. Auriculotherapy Manual (Chinese and Western Systems of Ear Acupuncture). 3th ed 2003; Reprinted 2004, 2005, 2006, 2007 (twice), 2008. www. elsevierhealth.com.

20. Seyyedzadeh Aghdam N, Vakilian K, DaM. Effect of BL32 and GB21 acupressure on labor pain in the first stage of labor. complementary Medicine Journal 2012;2:104-10.

21. Hadizadeh Talasaz Z, Khadivzadeh T, Firoozi M, Azizi H, Irani M. The Usage of Ear Acupressure in Gynecology and Obstetrics: A Systematic Review of Clinical Trials. Iran J Obstet, Gynecol Infertil 2018;21:42-54. (in persian).

22. Oleson T. Auriculotherapy Manual.4ed2015; 1. (in persian).

https://doi.org/10.1016/B978-0-7020-3572-2.00001-X

23. Farhadi M, Mahmoudian S, Yazdanparasti V, Daneshi A. Effects of auditory electrical stimulation (AES) on tinnitus improvement and associated complaints. Hakim Research J 2005;8:18. (in persian).

24. Acar HV. Acupuncture and related techniques during perioperative period: A literature review. Complement Ther Med 2016;29:48-55. https://doi.org/10.1016/j.ctim.2016.09.013 
25. Lau KS, Jones AY. A single session of Acu-TENS increases FEV1 and reduces dyspnoea in patients with chronic obstructive pulmonary disease: a randomised, placebo-controlled trial. Aust J Physiother 2008;54:179-84. https://doi.org/10.1016/S0004-9514(08)70024-2

26. Mousavi FSG, Bahrami HR. Comparison of the effect of foot reflexology and Auriculotherapy on pain and anxiety in women following elective cesarean section. Mashhad, Iran 2016 (in persian).

27. Di Benedetto P, Iona L, Zidarich V. Clinical evaluation of S-adenosyl-L-methionine versus transcutaneous electrical nerve stimulation in primary fibromyalgia. Curr Ther Res 1993;53:222-9. https://doi.org/10.1016/S0011-393X(05)80250-4

28. Wu L, Cui C, Han J. Reduction of methadone dosage and relief of depression and anxiety by 2/100 Hz TENS for heroin detoxification. Chinese JDD. 2001;2:016.

29. Robb KA, Newham DJ, Williams JE. Transcutaneous electrical nerve stimulation vs. transcutaneous spinal electroanalgesia for chronic pain associated with breast cancer treatments. J Pain Symptom Manage 2007;33:410-9.

https://doi.org/10.1016/j.jpainsymman.2006.09.020

30. Mousavi FS, Golmakani N, Bahrami H, et al. Effects of auriculotherapy on post cesarean anxiety. EBCJ 2017;20:50-60. (in persian).

31. Pilkington K, Kirkwood G, Rampes H, et al. Acupuncture for anxiety and anxiety disorders-a systematic literature review. Acupunct Med 2007;25:1-10.

https://doi.org/10.1136/aim.25.1-2.1

32. Zamani M, Torabian S. Evaluation the Colposcopic and Histologic Findings in Oncology Ward Of Fatemieh Hospital, Hamadan, Iran. EBCJ 2013;16:1-6.(in persian).

33. Barnes LL, Harp D, Jung WS. Reliability generalization of scores on the Spielberger statetrait anxiety inventory. Educ Psychol Meas 2002;62:603-18. https://doi.org/10.1177/0013164402062004005

34. Jouya S, Golmakani N, Mazloum SR, et al. Effect of Auriculotherapy with Vaccaria Seeds on the Anxiety of Female Colposcopy Candidates. EBCJ 2018;21:70-9 (in persian). https://doi.org/ 10.22038/EBCI.2017.27683.1653

35. Karst M, Winterhalter M, Münte S, et al. Auricular acupuncture for dental anxiety: a randomized controlled trial. Anesth Analg 2007;104:295-300. https://doi.org/10.1213/01.ane.0000242531.12722.fd

36. Hashemy S, Zakerimoghadam M. Comparative study of the effect of muscle relaxation and music therapy on anxiety level in patients waiting for cardiac catheterization. ICNS. 2013;1:22-30. (in persian).

https://doi.org/10.4103/nms.nms 9018

37. Grös DF, Antony MM, Simms LJ, McCabe RE. Psychometric properties of the State-Trait Inventory for Cognitive and Somatic Anxiety (STICSA): comparison to the State-Trait Anxiety Inventory (STAI). Psychol Assess 2007;19:369. https://doi.org/10.1037/1040-3590.19.4.369

38. Ahmadian N. Relationship between Personality Factors and Locus of Control with Test Anxiety in Birjand's High school Students. JEPS 2014;10:1-20 (in persian).

39. Mousavi FS, Bahrami Taghanaki HR, Saki A, Akhlaghi F. Comparison of the effect of foot reflexology and Auriculotherapy on pain and anxiety in women following elective cesarean section: Mashhad University of Medical Sciences; 2016.( in persian). 


\title{
Uticaj transkutane aurikularne stimulacije na anksioznost pre kolposkopije: randomizirana klinička studija
}

\author{
Samaneh Jouya, Nahid Golmakani \\ Istraživački centar za sestrinstvo i akušerstvo, Univerzitet medicinskih nauka u Mašhadu, Iran
}

\author{
SAŽETAK
}

Žene doživljavaju visok stepen anksioznosti i negativnih emocija za vreme kolposkopije, što dovodi do nepojavljivanja na kontrolne preglede. Transkutana aurikularna stimulacija može pomoći u smanjenju anksioznosti. Stoga je cilj ove studije bio određivanje uticaja transkutane aurikularne stimulacije na smanjenje anksioznosti pre kolposkopije. Ova randomizirana kontrolna klinička studija uključila je 65 kandidatkinja za kolposkopiju koje su upućene u bolnicu Ghaem u Mašhadu, u Iranu, 2017. godine. Učesnice studije su nasumično podeljene $u$ dve grupe. U interventnoj grupi "pointer" Ecel uređaj je korišćen u trajanju od četrdeset minuta pre kolposkopskog pregleda. Električna stimulacija je rađena preko četiri akumpukturne tačke na ušima (Shenmen, tačka za relksaciju, za smirenje i preko endokrine tačke), sa frekvencijom od $2 \mathrm{~Hz}$ u trajanju od 30 sekundi na svakoj akumpukturnoj tački. Žene u kontrolnoj grupi su primile rutinski tretman. Stepen anksioznosti je procenjivan Spilbergovim upitnikom pre, ali i 40 minuta nakon intervencije. Prikupljeni podaci analizirani su primenom t-testa, uparenog t-testa, kao i primenom Mann-Whitney testa, SPSS softver, verzija 16. P vrednost manja od 0,05 je uzeta kao signifikantna. Nakon intervencije, skor anksioznosti kao crte ličnosti iznosio je 43,9 $\pm 9,19$ u kontrolnoj grupi i 54,3 $\pm 9,07$ u interventnoj grupi, a razlika između dveju grupa bila je statistički značajna $(P=0,00)$, dok značajna razlika nije zabeležena u nivou anksioznosti kao crte ličnosti između ovih grupa $(P=0,21)$. Što se tiče smanjenja nivoa trenutne anksioznosti nakon intervencije, transkutana aurikularna stimulacija preporučuje se kao pogodna metoda za smanjenje anksioznosti kod pacijentkinja koje su kandidati za kolposkopiju.

Ključne reči: anksioznost, kolposkopija, aurikuloterapija, električna stimulacija 